\title{
Effects of a home follow-up program in Turkey for urban mothers of premature babies
}

\author{
Nebahat Bora Güneş MSc, PhD (D) | Hicran Çavuşoğlu MSc, PhD (ID
}

Department of Child Health and Diseases Nursing, Hacettepe University Nursing

Faculty, Ankara, Turkey

\section{Correspondence}

Nebahat Bora Güneş, Department of Child Health and Diseases Nursing, Hacettepe University Nursing Faculty, D Block Altındağ - Ankara, Turkey.

Email: nebahatgunes@gmail.com

\section{Funding information}

Hacettepe Üniversitesi, Grant/Award

Number: THD-2016-8472

[Correction added on 14 November 2019, after first online publication: The following changes have been made to the article: (1) in the article title, 'turkey' has been changed to 'Turkey'; (2) author degree 'MD' has been added to the first author; and (3) in Funding information, grant/award number has been changed from ' $8200 \mathrm{TL}$ ' to 'THD-2016-8472'. ]

[Correction added on 10 January 2020, after first online publication: the author's academic credential has been changed from 'MD' to 'MSc'.]

\begin{abstract}
Objective: To examine the effects of a home follow-up program in Turkey on care problems, anxiety, and depression levels of mothers after the birth of a premature baby.

Methods: A semi-experimental study with a pretest-posttest control group design. Eighty premature newborns and their mothers were included in the study. Nursing care was given to mothers and babies in the study group through a total of four home visits on weeks 1, 2, 3, and days 40-42 in Kırıkkale, Turkey guided by the Nursing Diagnosis System and Nursing Interventions Classification (NIC) system of the North American Nursing Diagnosis Association (NANDA). Data were collected from a sociodemographics form, home care needs evaluation form, Edinburgh Postpartum Depression Scale, and State Anxiety Inventory.

Results: There were no significant differences between groups for nursing diagnoses at baseline, while the study group resulted in significantly fewer problems on days 40-42, compared to the control group. Mothers had a comparatively lower depression and state anxiety risk in the study group compared to the control group.

Conclusions: Providing home-based nursing care for preterm mothers and babies during the first 40-42 days has the potential to decrease postnatal care problems, including maternal depression and state anxiety levels.
\end{abstract}

\section{KEYWORDS}

anxiety, baby care, depression, home follow-up, premature infant

\section{1 | BACKGROUND}

The experience of premature delivery, and the subsequent need for care in a newborn intensive care unit, is generally perceived as traumatic and a possible cause of psychological distress among mothers (Arslan \& Turgut, 2013; Bağcı \& Altuntuğ, 2016; Horwitz et al., 2015; Zelkowitz, Papageorgiou, Bardin, \& Wang, 2009). Mothers may experience depression and anxiety around the appearance and health of their infant, difficulties experienced while receiving care, feelings of guilt regarding a premature birth, and concerns for the infant's prognosis (Melnyk, Crean, Feinstein, \& Fairbanks, 2008; Premji et al.,
2018). In a systematic review performed by Özcan and colleagues, one of the most prevalent risk factor for postnatal depression was determined as gestastional week and postnatal depression was higher among mothers who had premature babies as compared to full-term mothers (Özcan, Boyacıoğlu, \& Dinç, 2017; Vigod, Villegas, Dennis, \& Ross, 2010). More recent studies examining factors related to anxiety and depression, showed that mothers' self-confidence and stress regarding care for their infant significantly affected their moods (Falah-Hassani, Shiri, \& Dennis, 2016; Field, 2018).

Premature babies' transition from the hospital to home, along with their home care, involves multidimensional and complex 
processes. These processes are best accommodated by evaluating each newborn and family's individual requirements through appropriate nursing care (Lopez, Anderson, \& Feutchinger, 2012). Nurses are responsible for evaluating parents' ability to care for their infant within the home environment while facilitating postdelivery adaptation. Supporting mothers of premature babies enhances the quality of care provided to babies and positively influences mothers' coping and psychosocial well-being (Galeano \& Carvajal, 2016).

Although most mothers and their infants around the world receive some type of postnatal care (McPherson \& Hodgins, 2018), the nature and frequency of this care varies significantly. In Turkey, there is no public or private home monitoring system provided for newborn babies, nor is there any special service for home care provided to such mothers. Babies discharged from hospital are referred to neonatal outpatient clinic physical evaluation visits during for day 7, 15 and 30. No data are available about hospitalization of mothers and newborns during the postnatal period or information about postdischarge care received at home (Republic of Turkey Ministry of Health, 2016). This is especially problematic for mothers with premature babies, who often have issues with home care.

Nursing care is effective for maintaining a baby's health while also helping to increase parents' knowledge, skills, and self-confidence regarding care. Nurses can help to minimize the stress and anxiety parents experience during the transition to the home, and reduce the baby's morbidity and mortality risk. (Boykova \& Kenner, 2012; Sassa, Gaiva, Higarashi, \& Marcon, 2014). The present study assessed the effects of a home-based nursing care program on postnatal care problems, anxiety and depression among Turkish women with premature babies.

\section{2 | METHODS}

\section{1 | Design and sample}

A semi-experimental design, including a pretest and posttest control group, was employed to assess four home-based nursing care visits provided by one of the researchers (a pediatric nurse with experience in a newborn intensive care unit and home care for children with chronic diseases). The program was based in a hospital that provides services for several cities, including both rural and urban areas.

Participants were mothers and babies delivered before 37 weeks in a university hospital in Kırıkkale, Turkey. Ninety-four babies were born before 37 weeks during the study period: June 1, 2015-July 1 , 2016. The inclusion criteria that were used are as follows: primiparous, delivered before 37 weeks of gestation, no disease that could affect postnatal care, no hearing/speaking disability, a 5-min Apgar score $>7$, normal postnatal examination, and hospital discharge within $24 \mathrm{hr}$ of birth. Exclusion criteria included mothers who had any disease condition, medical physical/mental problems at followup, a history of medication use during the prenatal period, or a baby who underwent resuscitation during delivery or had a congenital malformation.
Sample size and power were evaluated with a post hoc power analysis (PASS Version 11.0): 0.93 for postnatal depression and 0.98 for anxiety.

\section{2 | Measures}

\subsection{1 | Sociodemographic data}

Twenty demographic questions were completed by the participants.

\subsection{2 | Mothers' needs at home}

Forty two items, based on the literature, questioned whether mothers felt prepared to care for their baby; care categories included feeding, bathing, and diaper changes (Çavuşoğlu, 2019; Doğum Sonu Bakım Yönetim Rehberi, 2014). Two neonatology experts and two newborn nurses assessed content validity index to be acceptable for all items (between 0.81 and 1.00) (Davis, 1992).

\subsection{3 | Edinburgh postnatal depression scale}

This scale was developed by Cox, Holden, and Sagovsky (1987) and later adapted into Turkish (Engindeniz, Küey, \& Kültür, 1996). The measure was self-rated on a 4-point Likert-type (0-3 points) scale including 10 items asking individuals to rate their depression symptoms during the previous week. Total scores range from $0-30$. The cutoff for determining depression risk is $12-13$ in the Turkish version. Internal consistency (Cronbach's alpha) was 0.87 for the original scale (Cox et al., 1987) and 0.79 for the Turkish version (Engindeniz et al., 1996). Cronbach's alpha for the present sample was 0.87 .

\subsubsection{The Spielberg State Anxiety Inventory}

The State Anxiety Inventory was developed by Spielberger (1970) and was adapted into Turkish by Öner and Le Compte (1998). The measure includes 20 items that are self-rated on a 4-point Likert-type scale for determining current anxiety levels. Total scores range from 20-80: "no anxiety" = 0-19 points, "mild anxiety" $=$ 20-39 points, "moderate anxiety" $=40-59$ points, and "severe anxiety" $=60-80$ points. The cutoff for determining risk for anxiety is $\geq 40$ (Dennis, Coghlan, \& Vigod, 2013). The Cronbach's alpha for the Turkish version of the scale was 0.93 (Öner \& Le Compte, 1998). The Cronbach's alpha for the present sample was 0.94 .

\subsection{5 | Infant physical evaluation}

At each follow-up, infants were physically examined including their body temperature, pulse rate, respiration rate, blood pressure, peripheral saturation, height, body weight, and head circumference. A sphygmomanometer, stethoscope, tympanic thermometer, baby scale, height gauge, and measuring tape were used for this purpose. 


\subsection{6 | Nursing diagnoses}

At the home follow-up visits, an experienced pediatric nurse evaluated problems encountered by the mother and completed a nursing diagnosis form using the NANDA nursing diagnostic system, and nursing activities were planned using the NIC nursing interventions taxonomy (NANDA International, 2014). A nursing care plan using the nursing interventions classification taxonomy was prepared for each mother and her baby based on these evaluations.

Data collection and all home visits were conducted by the first author. Nursing diagnoses were determined by the first and second authors together according to the data collected by the first author. All mothers in the study group received four regular visits from the first author.

\section{3 | Intervention}

Mothers and their babies were visited at the hospital within the first $24 \mathrm{hr}$ postdelivery. The first mother was assigned to the control group by using a toss-up method; subsequent mothers and their babies were assigned to study and control groups, respectively.

For both intervention and control groups, the sociodemographic data collection form, needs evaluation form, Edinburgh Postnatal Depression Scale, Spielberg State Anxiety Inventory, and infants' physical examinations were completed. Nursing interventions were identified according to the NIC in accordance with nursing diagnoses that were generated.

For the intervention group, four home follow-ups were performed for the study group at weeks 1, 2, 3, and days 40-42. Each home follow-up lasted approximately $40-60 \mathrm{~min}$. At each home follow-up, problems experienced by the mother in terms of postnatal (along with subsequent) care requirements, were re-evaluated. Care was also provided during the home follow-ups. Any problems detected during the visits were addressed immediately. Basic care skills (e.g., changing diapers, diaper rash care, skin care, bathing, dressing, etc.) were performed with mothers to promote appropriate skills. At the end of the fourth visit, days 40-42, final data collection occurred.

For the control group, no other care was provided outside of what was offered at the hospital. A visit for final data collection occurred between days 40-42.

\subsection{Ethical considerations}

Ethical approval was obtained from the ethics committee of the authors' university, and written authorization was granted from the hospital. All mothers provided written informed consent. This study complied with the ethical rules for human experimentation that are stated in the Declaration of Helsinki. The mothers included in the control group only received routine training at the hospital; however, any questions they had at the hospital were answered. After data collection, between days 40-42, nursing care was given to women in the control group as per their needs.

\section{5 | Analytic strategy}

Data were analyzed using SPSS (version 22.0). Descriptive statistics are given as numbers and percentages (\%) for the identified variables and as means \pm standard deviations $(S D)$ and median and minimum-maximum (min-max) values for the main variables of interest. Differences between the study and control groups concerning sociodemographic characteristics were compared using chi-square and Mann-Whitney $U$ tests. Chi-square tests were also used to assess differences between the study and control groups concerning nursing diagnoses within the first $24 \mathrm{hr}$ and at days 40-42 postdischarge. Mann-Whitney $U$ tests were also used to assess differences between postnatal depression and anxiety levels.

\section{3 | RESULTS}

\section{1 | Participant characteristics}

Of the 94 eligible mothers, 13 did not wish to participate, and one mother moved out of the city after the first home follow-up. Thus, the final sample included 80 mothers and their babies. Forty mothers were enrolled in each group (study and control). Table 1 presents mothers' and babies' demographic data. No significant demographic differences were identified between the groups.

\section{2 | Nursing diagnoses}

There were no significant differences between the study and control groups concerning nursing diagnoses identified within the first $24 \mathrm{hr}$ at the hospital. At days 40-42 postdischarge, significant differences were observed for several diagnoses, with the study group having significant fewer problems with ineffective feeding $(p<.001)$,impaired parenting ( $p=.005)$, caregiver role strain $(p<.001)$, sleep pattern disturbance $(p=.023)$, anxiety $(p=.006)$, fatigue $(p=.019)$, lack of leisure activities ( $p=.022$ ), ineffective coping $(p<.001)$, deficient knowledge $(p<.001)$ and dysfunctional family processes $(p<.001)$. Moreover, a diagnosis of impaired skin integrity (on nipples) was added as a difference observed in the control group (Table 2).

When nursing diagnoses for infants were examined, no significant differences were found within the first $24 \mathrm{hr}$. During days 40-42 postdischarge, significant differences were observed for several diagnoses, with the study group having significant fewer problems with impaired skin integrity (diaper dermatitis) ( $p=.003$ ), disrupted oral mucous membrane $(p=.041)$, imbalanced nutrition ( $p=.041$ ), acute pain (colic) ( $p=.034)$, disorganized infant behavior ( $p=.024$ ), sleep pattern disturbance $(p=.027)$, infection (umbilical cord) $(p=.041)$, risk for imbalanced body temperature $(p=.041)$, risk for trauma $(p<.001)$, and risk for aspiration $(p<.001)$ (Table 3$)$.

\section{3 | Mothers' depression and anxiety levels}

Differences between mothers' mean depression and anxiety scores by group were significant after the home follow-ups. 
TAB LE 1 Descriptive study and control group characteristics

\begin{tabular}{|c|c|c|c|c|c|}
\hline \multicolumn{6}{|l|}{ Infant characteristics } \\
\hline \multirow[b]{2}{*}{ Characteristic } & \multicolumn{2}{|l|}{ Study group $(n=49)$} & \multicolumn{2}{|c|}{ Control group $(n=45)$} & \multirow[b]{2}{*}{$p$} \\
\hline & $n$ & $\%$ & $n$ & $\%$ & \\
\hline \multicolumn{6}{|l|}{ Number of infants } \\
\hline Twin & 18 & 36.7 & 10 & 22.2 & \multirow[t]{2}{*}{.099} \\
\hline Single & 31 & 63.7 & 35 & 77.7 & \\
\hline Birth week & $34.65 \pm 1.217$ & $31-36$ & $34.18 \pm 1.211$ & $32-36$ & .393 \\
\hline Birth weight (grams) & $2,396.0 \pm 362.5$ & $1820-3175$ & $2,444.4 \pm 285.8$ & $1920-3020$ & .229 \\
\hline \multicolumn{6}{|l|}{ Apgar score } \\
\hline 1st min & $8.86 \pm 1$ & $7-10$ & $8.47 \pm 1$ & $7-10$ & .546 \\
\hline Characteristic & $\bar{X} \pm S D$ & Min-max & $\bar{X} \pm S D$ & Min-max & $p$ \\
\hline \multirow[t]{2}{*}{ Maternal age (years) } & $24.18 \pm 4,3,674.367$ & $18-41$ & $24.30 \pm 4.165$ & $18-34$ & .858 \\
\hline & $n$ & $\%$ & $n$ & $\%$ & \\
\hline \multicolumn{6}{|l|}{ Type of delivery } \\
\hline Vaginal & 8 & 20.0 & 13 & 32.5 & .786 \\
\hline Cesarean & 32 & 80.0 & 27 & 67.5 & \\
\hline \multicolumn{6}{|l|}{ Education level } \\
\hline University & 13 & 30.0 & 9 & 22.5 & .924 \\
\hline Yes & 4 & 10.0 & 5 & 12.5 & .725 \\
\hline No & 36 & 90.0 & 35 & 87.5 & \\
\hline \multicolumn{6}{|c|}{ Problems during pregnancy } \\
\hline Yes & 33 & 82.5 & 36 & 90.0 & .763 \\
\hline No & 7 & 17.5 & 4 & 10.0 & \\
\hline \multicolumn{6}{|l|}{ Any support for care } \\
\hline Yes & 24 & 60.0 & 26 & 65.00 & .646 \\
\hline No & 16 & 40.0 & 14 & 35.00 & \\
\hline
\end{tabular}

Abbreviations: $\bar{X}$, mean scores; SD, standard deviation.

No significant depressive symptoms were observed among mothers in both groups within the first $24 \mathrm{hr}$ for both depression and anxiety levels. Differences between mothers' mean depression and anxiety scores by group were significant after the home followups; depression scores in the control group exceeded the 12-point cutoff at days 40-42 (Table 4). Mothers in the control group had moderate anxiety (40-59 points), while mothers in the study group had mild anxiety (20-39 points) within the first 24 hours. Anxiety levels were significantly higher among mothers in the control group
$(\bar{X} \pm S D=50.50 \pm 9.99)$ on days 40-42 in comparison to the study group $(\bar{X} \pm S D=44.63 \pm 8.86)(p<.001)($ Table 5$)$.

\section{4 | DISCUSSION}

In this study of follow-up home care for new mothers and their babies, differences between the groups were observed in eight out of 10 nursing diagnoses for mothers. When nursing diagnoses for 
TAB LE 2 Nursing diagnoses for mothers within the first $24 \mathrm{hr}$ and on days 40-42 $(n=40)$

\begin{tabular}{|c|c|c|c|c|c|c|c|c|c|c|}
\hline Nursing diagnoses & \multicolumn{5}{|c|}{ First $24 \mathrm{hr}$} & \multicolumn{5}{|c|}{ Days 40-42 } \\
\hline Ineffective feeding & 40 & 100.0 & 40 & 100.0 & 1.000 & 2 & 5.0 & 22 & 55.0 & $<.001$ \\
\hline Impaired parenting & 1 & 2.5 & 3 & 7.5 & .308 & 2 & 5.0 & 14 & 35.0 & .005 \\
\hline Sleep pattern disturbance & 4 & 10.0 & 2 & 5.0 & .399 & 5 & 12.5 & 16 & 40.0 & .023 \\
\hline Anxiety & 0 & 0.0 & 2 & 5.0 & .155 & 0 & 0.0 & 7 & 17.5 & .006 \\
\hline Fatigue & 6 & 15.0 & 7 & 17.5 & .534 & 4 & 10.0 & 15 & 37.5 & .019 \\
\hline Lack of leisure activities & 0 & 0.0 & 0 & 0.0 & 1.000 & 0 & 0.0 & 5 & 12.5 & .022 \\
\hline $\begin{array}{l}\text { Impaired skin integrity } \\
\text { (nipples) }\end{array}$ & 0 & 0.0 & 0 & 0.0 & 1.000 & 0 & 0.0 & 8 & 20.0 & .003 \\
\hline
\end{tabular}

Bold values are $<0.05$.

TAB LE 3 Nursing diagnoses for infants within the first $24 \mathrm{hr}$ and on days $40-42$

\begin{tabular}{|c|c|c|c|c|c|c|c|c|c|c|}
\hline Nursing diagnoses & \multicolumn{5}{|c|}{ First $24 \mathrm{hr}$} & \multicolumn{5}{|c|}{ Days 40-42 } \\
\hline $\begin{array}{l}\text { Impaired skin integrity } \\
\text { (diaper dermatitis) }\end{array}$ & 0 & 0.0 & 0 & 0.0 & 1.000 & 0 & 0.0 & 8 & 17.7 & .003 \\
\hline $\begin{array}{l}\text { Impaired skin integrity } \\
\text { (dermatitis) }\end{array}$ & 0 & 0.0 & 0 & 0.0 & 1.000 & 0 & 0.0 & 2 & 4.4 & .155 \\
\hline $\begin{array}{l}\text { Disrupted oral mucous } \\
\text { membrane }\end{array}$ & 0 & 0.0 & 0 & 0.0 & 1.000 & 0 & 0.0 & 4 & 8.8 & .041 \\
\hline Imbalanced nutrition & 0 & 0.0 & 0 & 0.0 & 1.000 & 0 & 0.0 & 4 & 8.8 & .041 \\
\hline Hyperthermia & 0 & 0.0 & 0 & 0.0 & 1.000 & 0 & 0.0 & 2 & 4.4 & .155 \\
\hline Acute pain (colic) & 0 & 0.0 & 0 & 0.0 & 1.000 & 4 & 8.1 & 14 & 31.1 & .034 \\
\hline $\begin{array}{l}\text { Disorganized infant } \\
\text { behavior }\end{array}$ & 0 & 0.0 & 0 & 0.0 & 1.000 & 3 & 6.1 & 11 & 24.4 & .024 \\
\hline $\begin{array}{l}\text { Sleep pattern } \\
\text { disturbance }\end{array}$ & 0 & 0.0 & 0 & 0.0 & 1.000 & 5 & 10.2 & 11 & 24.4 & .027 \\
\hline Infection (umbilical cord) & 40 & 100.0 & 40 & 100.0 & 1.000 & 0 & 0.0 & 4 & 8.8 & .041 \\
\hline $\begin{array}{l}\text { Risk for imbalanced body } \\
\text { temperature }\end{array}$ & 0 & 0.0 & 0 & 0.0 & 1.000 & 0 & 0.0 & 4 & 8.8 & .041 \\
\hline
\end{tabular}

Bold values are $<0.05$. 
TAB LE 4 Comparison of mothers' mean postnatal depression scores within the first $24 \mathrm{hr}$ and on days $40-42$

\begin{tabular}{|c|c|c|c|c|c|c|c|c|c|c|c|}
\hline & \multicolumn{4}{|c|}{ Study group } & \multicolumn{4}{|c|}{ Control group } & U & z & $p$ \\
\hline EPDS Posttest & 40 & $6.63 \pm 4.09$ & 0.648 & $0-15$ & 40 & $12.68 \pm 5.76$ & 0.911 & $2-26$ & 322.000 & -4.611 & $<.001$ \\
\hline
\end{tabular}

Abbreviations: $\bar{X}$, mean scores; SD, standard deviation; SE, standard error; EPDS, Edinburg Postnatal Depression Scale. Bold values are $<0.05$

TAB LE 5 Comparison of mothers' mean state anxiety scores within the first $24 \mathrm{hr}$ and on days $40-42$

\begin{tabular}{|c|c|c|c|c|c|c|c|c|c|c|c|}
\hline & \multicolumn{4}{|c|}{ Study group } & \multicolumn{4}{|c|}{ Control group } & \multirow[b]{2}{*}{ U } & \multirow[b]{2}{*}{ Z } & \multirow[b]{2}{*}{$p$} \\
\hline & $n$ & $\bar{X} \pm S D$ & SE & Min-max & $n$ & $\bar{X} \pm S D$ & SE & Min-max & & & \\
\hline $\begin{array}{l}\text { State anxiety } \\
\text { posttest }\end{array}$ & 40 & $38.90 \pm 6.93$ & 1.096 & $30-59$ & 40 & $50.50 \pm 9.99$ & 1.580 & $33-68$ & 287.000 & -4.945 & $<.001$ \\
\hline
\end{tabular}

Bold values are $<0.05$.

Abbreviations: $\bar{X}$, mean scores; SD, standard deviation; SE, standard error.

infants were compared between groups, differences for all except dermatitis, conjunctivitis, diarrhea, constipation, hypothermia, and hyperthermia were significant. Thus, nursing care provided to the study group resulted in significantly fewer problems faced by primiparous mothers and their babies.

In a previous systematic review (Lopez et al., 2012), studies addressing the transfer of families with premature babies from the hospital to home were examined, and five common components were identified: maintaining communication with the family at home, making home visits, evaluating the baby's health and conditions at home, education, and inclusion of nurses in all of these processes. The final component was deemed most important. In our study, babies and mothers in the study group experienced significantly fewer problems compared to the control group. This finding supports the efficiency and necessity of nursing care and education, especially in premature delivery cases, where babies and mothers require special attention.

\section{1 | Nursing diagnoses for mothers}

Nursing diagnoses, including sleep pattern disturbances and fatigue, decreased by providing nursing care interventions for strengthening sleep, improving participation of the family in care, and supporting caregivers through home follow-ups. However, this was not same for all mothers in the study group.

In a study investigating problems and care needs among mothers, and the relationship between postnatal support and problems experienced at 9 months postdelivery, Yıldız and Küçükşahin (2011) found that issues concerning daily living activities, sleep, and rest were among the most commonly experienced by mothers. It was also reported that these problems were significantly less frequent among mothers who received postnatal professional support (Xie, He, Koszycki, Walker, \& Wen, 2009), which is consistent with the present findings. Dysfunctional family processes have been observed among $30 \%$ of families with premature babies due to problematic caregiving, mothers' fatigue and sleep deprivation, and anxiety and ineffective coping strategies owing to a lack of knowledge when it comes to caring for a preterm infant. Inexperience and a baby's special care needs during the postnatal period may create feelings of inadequacy among mothers within a new domestic role; however, such problems can be mitigated within a few weeks postintervention. In the control group, the "dysfunctional family processes" diagnosis was observed in approximately $40 \%$ of families at the end of the study period, which was significantly greater compared to the study group.

\section{2 | Nursing diagnoses for infants}

In the study group, a risk for umbilical cord infection was addressed in nearly two-thirds of infants during the first week. However, this issue was eliminated by the second week owing to proper nursing care (i.e., keeping the umbilical cord dry and clean, using water and soap with a $\mathrm{pH}$ compatible with the skin, lack of contact with the diaper, keeping the cord outside the diaper, protecting the cord from urine and stool contamination, being careful while bathing, dressing, and cuddling the baby). At days 40-42, umbilical cord infection risk was identified among four babies in the control group. This difference between groups was significant. Colic was observed in $14.2 \%$ of babies in the study group, while disorganized infant behavior was observed in $6.1 \%$ during the first week. Increases in both diagnoses were observed during the second week at home follow-ups, and these problems were not completely 
resolved for all babies during the subsequent follow-ups (although decreases were observed). These diagnoses significantly differed between the study and control groups. Sleep pattern disturbances decreased by the 4th week of follow-up nursing care, which also significantly differed between groups. During the first follow-up visit, aspiration and trauma risks were observed; however, these were resolved after two weeks of nursing care. At days 40-42, significant differences were observed between both groups. In the postpartum period, the mother may experience self-distrust and insecurity in the care of the baby because of the physical problems of their own, the unanticipated delivery of birth and the consequence of the family not being fully prepared for the new family member and the family's concerns about the baby's health condition. These results support the fact that in the newborn period, which is an adaptation period for both the family and the infant, it is necessary to provide qualified nursing care and education for the infant and the mother, which should be individualized according to the needs of the mothers and their babies after being discharged from the hospital (Galeano \& Carvajal, 2016; Wittmann-Price, 2016; Yıldız \& Küçükşahin, 2011).

\section{3 | Mothers' depression and state anxiety}

In Turkey, mean postnatal depression scores range from 9.8 to 10.4 , and depression incidence rates vary from $6.5 \%$ to $48.3 \%$ (Boratav, Toker, \& Küey, 2016; Kartal \& Simsek, 2017). Similar results have been reported worldwide (Dennis et al., 2013; Field, 2018; Garfield et al., 2015; Helle et al., 2016). In prior studies investigating factors underlying anxiety and depression, maternal stress and self-confidence, state of breastfeeding, and baby care are key factors (Dennis et al., 2013; Field, 2018; Garfield et al., 2015).

In this study, maternal depression scores within the study group during the first $24 \mathrm{hr}$ were similar to those in past studies; however, depression scores at the end of the study period were lower when compared to the control group and prior results, highlighting a potential area of effectiveness with the intervention. Support received may enable mothers to emotionally and cognitively cope with stress and anxiety more easily. Furthermore, individualized nursing care appeared to be effective in decreasing depression levels beyond the support provided for infant care. An increase in postnatal depression is often observed within the first 30 days; this is in keeping with prior studies showing that depression scores on days 40-42 were higher compared to the first $24 \mathrm{hr}$ (Canário \& Figueiredo, 2017; Welch et al., 2016). Therefore, follow-up interventions are especially recommended for women at risk for postpartum depression after preterm delivery (Canário \& Figueiredo, 2017; Vigod et al., 2010; Welch et al., 2016).

Mothers' mean state anxiety scores also decreased after the follow-up visits in the study group, but scores increased among the control group. In some previous studies, mean state anxiety scores varied between 39 and 44 (Dennis et al., 2013; Field, 2018; Helle et al., 2016), which coincided with results obtained among our controlgroup mothers (Table 5) .
Among mothers with premature infants, state anxiety is often associated with feelings of guilt and concerns over the baby's appearance and condition (Falah-Hassani et al., 2016; Horwitz et al., 2015). Delivery-associated fatigue may also increase mothers' anxiety, especially primiparous mothers, due to being dependent on self-care following the delivery and lacking sufficient "alone" time (Bağcı \& Altuntuğ, 2016). Here, mothers should be educated on effective coping strategies (Davidson, London, \& Ladewig, 2015). In this study, state anxiety scores decreased after several weeks of at-home nursing interventions. This could partly be due to the fact that mothers were provided information on baby care, strategies for decreasing anxiety, means for strengthening coping methods, and supportive decision-making.

Late premature newborns were included in the present sample due to limitations with our inclusion criteria. In recent years, approximately $75 \%$ of all premature births are late term (Shapiro-Mendoza \& Lackritz, 2012). Additionally, the health risks for these infants may be overlooked due to their appearance being similar to full-term newborns. Therefore, higher risk of mortality and morbidity that requires medical attention, increased health care needs after birth hospitalization leading to greater health care cost and the cost for postdischarge visits for late-term premature infants has become an emerging research area. The current findings and public heath impact of such preventive strategies, if replicated, could assist in further prevention efforts for neonatal health problems postdischarge.

\section{4 | Study limitations}

A few study limitations should be noted. First, one of the researchers was not blind to the experimental and control group assignment, which could lead to biases of nursing diagnoses. To address this issue, a second researcher was blind to group assignment when providing a diagnosis. Second, the present findings may not be generalizable to populations with different sociodemographic characteristics outside of Turkey. Thus, studies in other countries with diverse samples are necessary to corroborate the present findings.

\section{5 | CONCLUSION}

Turkey, and a significant majority of developing countries, does not have programs for monitoring preterm mothers and infants. Our results have implications for nursing care in Turkey and suggest that home visits could be important in reducing the depression and anxiety symptoms among mothers. Such services could be especially useful when provided with social security coverage.

We suggest four actions: mothers with premature babies should be supported postdischarge; home environments and caregiving skills should be evaluated; and mothers should be screened for depression and anxiety; mothers deemed at-risk should have their psychosocial needs appropriately addressed. Given that continuity of care is critical for decreasing maternal and infant mortality, especially among high-risk groups such as premature infants, follow-up nursing intervention programs are vital. 
For future studies, we suggest to compare the efficacy of home visit programs of mothers with premature babies by the hospital health care providers who follow the baby from inception of him/ her life or by public health agencies; to determine the strategies and to evaluate the effectiveness of various home monitoring programs and their costs.

\section{ORCID}

Nebahat Bora Güneş (iD https://orcid.org/0000-0001-8264-7067

Hicran Çavuşoğlu (iD https://orcid.org/0000-0002-3808-4225

\section{REFERENCES}

Arslan, F. T., \& Turgut, R. (2013). Prematüre bebek annelerinin evdeki bakım gereksinimleri ve bakım verme yeterliliklerini algılama durumları. Dokuz Eylül Üniversitesi Hemşirelik Fakültesi Elektronik Dergisi, 6(3), https://dspace.deu.edu.tr/xmlui/handle/12345/4644

Bağcl, S., \& Altuntuğ, K. (2016). Problems experienced by mothers in postpartum period and their associations with quality of life Annelerin doğum sonunda yaşadıkları sorunlar ve yaşam kalitesi ile ilişkisi. Journal of Human Sciences, 13(2), 3266-3279. https://doi. org/10.14687/jhs.v13i2.3884

Boratav, H. B., Toker, Ö., \& Küey, L. (2016). Postpartum depression and its psychosocial correlates: A longitudinal study among a group of women in Turkey. Women \& Health, 56(5), 502-521. https://doi. org/10.1080/03630242.2015.1101737

Boykova, M., \& Kenner, C. (2012). Transition from hospital to home for parents of preterm infants. The Journal of Perinatal \& Neonatal Nursing., 26(1), 81-87. https://doi.org/10.1097/JPN.0b013e3182 43 e948

Canário, C., \& Figueiredo, B. (2017). Anxiety and depressive symptoms in women and men from early pregnancy to 30 months postpartum. Journal of Reproductive and Infant Psychology., 35(5), 431-449. https ://doi.org/10.1080/02646838.2017.1368464

Çavuşoğlu, H. (2019). Çocuk Sağlığı Hemşireliği: Yüksek riskli yenidoğan ve hemşirelik bakımı [Child health nursing: High-risk newborn and nursing care] (12th ed.). Ankara: Sistem Ofset Matbaacilık.

Cox, J. L., Holden, J. M., \& Sagovsky, R. (1987). Detection of postnatal depression: Development of the 10-item Edinburgh Postnatal Depression Scale. The British Journal of Psychiatry, 150(6), 782-786. https://doi.org/10.1192/bjp.150.6.782

Davidson, M., London, M., \& Ladewig, P. (2015). Olds' maternal-newborn nursing \& women's health across the lifespan. Upper Saddle River, NJ: Pearson.

Davis, L. L. (1992). Instrument review: Getting the most from a panel of experts. Applied Nursing Research, 5(4), 194-197. https://doi. org/10.1016/S0897-1897(05)80008-4

Dennis, C. L., Coghlan, M., \& Vigod, S. (2013). Can we identify mothers at-risk for postpartum anxiety in the immediate postpartum period using the State-Trait Anxiety Inventory? Journal of Affective Disorders, 150(3), 1217-1220. https://doi.org/10.1016/j.jad.2013.05.049

Doğum Sonu Bakım Yönetim Rehberi [Postpartum care management Guideline]. (2014). Ankara: T.C. Sağlık Bakanlığı Türkiye Halk Sağlığı Kurumu Kadın ve Üreme Sağıı̆ı Daire Başkanlığı. Retrieved from https://sbu.saglik.gov.tr/Ekutuphane/kitaplar/dsbyr_2.pdf

Engindeniz, A. N., Küey, L., \& Kültür, S. (1996). Edinburgh doğum sonrası depresyon ölçeği Türkçe formu geçerlilik ve güvenilirlik çalışması. Bahar Sempozyumları, 1, 51-52.

Falah-Hassani, K., Shiri, R., \& Dennis, C. L. (2016). Prevalence and risk factors for comorbid postpartum depressive symptomatology and anxiety. Journal of Affective Disorders, 198, 142-147. https://doi. org/10.1016/j.jad.2016.03.010

Field, T. (2018). Postnatal anxiety prevalence, predictors and effects on development: A narrative review. Infant Behavior and Development, 51, 24-32. https://doi.org/10.1016/j.infbeh.2018.02.005

Galeano, M. D., \& Carvajal, B. V. (2016). Coping in mothers of premature newborns after hospital discharge. Newborn and Infant Nursing Reviews, 16(3), 105-109. https://doi.org/10.1053/j. nainr.2016.08.007

Garfield, L., Holditch-Davis, D., Carter, C. S., McFarlin, B. L., Schwertz, D., Seng, J. S., ... White-Traut, R. (2015). Risk factors for postpartum depressive symptoms in low-income women with very low birth weight infants. Advances in Neonatal Care: Official Journal of the National Association of Neonatal Nurses, 15(1), E3. https://doi.org/10.1097/ ANC.0000000000000131

Helle, N., Barkmann, C., Ehrhardt, S., Von Der Wense, A., Nestoriuc, Y., \& Bindt, C. (2016). Postpartum anxiety and adjustment disorders in parents of infants with very low birth weight: Cross-sectional results from a controlled multicentre cohort study. Journal of Affective Disorders, 194, 128-134. https://doi.org/10.1016/j.jad.2016.01.016

Horwitz, S. M., Leibovitz, A., Lilo, E., Jo, B., Debattista, A., St. John, N., \& Shaw, R. J., (2015). Does an intervention to reduce maternal anxiety, depression and trauma also improve mothers'perceptions of their preterm infants'vulnerability? Infant Mental Health Journal, 36(1), 42-52. https://doi.org/10.1002/imhj.21484

Kartal, B., \& Simsek, N. (2017). The prevalence of depression during pregnancy and the affecting factors. Çağdaş Tıp Dergisi, 7(3), 217224. https://doi.org/10.16899/gopctd.349811

Lopez, G. L., Anderson, K. H., \& Feutchinger, J. (2012). Transition of premature infants from hospital to home life. Neonatal Network, 31(4), 207-214. https://doi.org/10.1891/0730-0832.31.4.207

McPherson, R., \& Hodgins, S. (2018). Postnatal home visitation: Lessons from country programs operating at scale. Journal of Global Health, 8(1), https://doi.org/10.7189/jogh.08.010422

Melnyk, B. M., Crean, H. F., Feinstein, N. F., \& Fairbanks, E. (2008). Maternal anxiety and depression following a premature infants' discharge from the NICU: Explanatory effects of the COPE program. Nursing Research, 57(6), 383. https://doi.org/10.1097/NNR.0b013 e3181906f59

NANDA International (2014). Nursing diagnoses 2012-14: Definitions and classification. West Sussex, UK: Wiley.

Öner, N., \& Le Compte, A. (1998). Sürekli durumluk/sürekli kaygı envanteri el kitabı. Yayınları, İstanbul: Boğaziçi Ün.

Özcan, N. K., Boyacıoğlu, N. E., \& Dinç, H. (2017). Postpartum depression prevalence and risk factors in Turkey: A systematic review and metaanalysis. Archives of Psychiatric Nursing, 31(4), 420-428. https://doi. org/10.1016/j.apnu.2017.04.006

Premji, S. S., Pana, G., Currie, G., Dosani, A., Reilly, S., Young, M., ... Lodha, A. K. (2018). Mother's level of confidence in caring for her late preterm infant: A mixed methods study. Journal of Clinical Nursing, 27(5-6), e1120-e1133. https://doi.org/10.1111/jocn.14190

Republic of Turkey Ministry of Health (2016). Health Statistics Yearbook. ISBN: 978-975-590-660-7. Retrieved from https://www.tandf. co.uk//journals/authors/style/reference/tf_A.pdf

Sassa, H. A., Gaiva, M. A. M., Higarashi, I. H., \& Marcon, S. S. (2014). Nursing actions in homecare to extremely low birth weight infant. Acta Paulista de Enfermagem, 27, 492-498. https://doi. org/10.1590/1982-0194201400080

Shapiro-Mendoza, C. K., \& Lackritz, E. M. (2012). Epidemiology of late and moderate preterm birth. Seminars in Fetal \& Neonatal Medicine, 17(3), 120-125. https://doi.org/10.1016/j.siny.2012.01.007

Spielberger, C. D. (1970). STAI manual for the state-trait anxiety inventory. Self-Evaluation Questionnaire,1-24.

Vigod, S. N., Villegas, L., Dennis, C. L., \& Ross, L. E. (2010). Prevalence and risk factors for postpartum depression among women with 
preterm and low-birth-weight infants: A systematic review. BJOG: an International Journal of Obstetrics \& Gynaecology, 117(5), 540-550. https://doi.org/10.1111/j.1471-0528.2009.02493.x

Welch, M. G., Halperin, M. S., Austin, J., Stark, R. I., Hofer, M. A., Hane, A. A., \& Myers, M. M. (2016). Depression and anxiety symptoms of mothers of preterm infants are decreased at 4 months corrected age with Family Nurture Intervention in the NICU. Archives of Women's Mental Health, 19(1), 51-61. https://doi.org/10.1007/ s00737-015-0502-7

Wittmann-Price, R. A. (2016). Caring for the newborns at risk. In S. L. Ward, S. M. Hisley, \& A. M. Kennedy (Eds.), Maternal- Child Nursing Care (pp.615-616, 634). Philadelphia, PA: F.A. Davis Company.

Xie, R. H., He, G., Koszycki, D., Walker, M., \& Wen, S. W. (2009). Prenatal social support, postnatal social support, and postpartum depression. Annals of Epidemiology, 19(9), 637-643. https://doi.org/10.1016/j. annepidem.2009.03.008
Yıldız, H., \& Küçükşahin, N. (2011). Kırsal bölgede annelerin doğum sonu yaşadıkları sorunlar ve bakım gereksinimleri. Turkish Journal of Family Practice/Türkiye Aile Hekimligi Dergisi, 15(4), https://doi.org/10.2399/ tahd.11.159

Zelkowitz, P., Papageorgiou, A., Bardin, C., \& Wang, T. (2009). Persistent maternal anxiety affects the interaction between mothers and their very low birthweight children at 24 months. Early Human Development, 85(1), 51-58. https://doi.org/10.1016/j.earlhumdev.2008.06.010

How to cite this article: Bora Güneş N, Çavuşoğlu H. Effects of a home follow-up program in Turkey for urban mothers of premature babies. Public Health Nurs. 2020;37:56-64. https:// doi.org/10.1111/phn.12671 